\title{
SPIRITUALITAS DAN KOMITMEN ORGANISASIONAL PADA ORGANISASI DAKWAH
}

\author{
Rahayu Dwi Candradini \\ STID Al-Hadid, Surabaya \\ rahayudwicandradini@gmail.com
}

\begin{abstract}
Abstrak: Organisasi dakwah merupakan organisasi nirlaba yang tidak memiliki visi material (keuntungan finansial), sehingga tidak menggunakan material sebagai instrumen untuk menggerakkan sumber daya manusianya. Spiritualitas di tempat kerja menjadi alternatif menggerakkan sumber daya manusia. Hasil riset terdahulu pada organisasi laba menunjukkan bahwa spiritual di tempat kerja berpengaruh positif terhadap komitmen pengurus pada organisasi. Sedangkan komitmen organisasi memiliki pengaruh yang cukup signifikan terhadap kinerja dan loyalitas pengurus pada organisasi. Studi ini meneliti spiritualitas di tempat kerja pada organisasi dakwah yang tidak melibatkan instrumen material untuk menggerakkan pengurusnya. Penelitian dilakukan khusus pada pengurus Jamaah Al-Khidmah Surabaya. Studi dilakukan berdasarkan teori spiritualitas di tempat kerja yang digagas oleh Milliman dkk dan Komitmen Organisasi yang digagas oleh Mowday dkk. Analisis menggunakan korelasi asosiatif Spearman's sedangkan data diperoleh dari hasil survei populasi yang berjumlah 19 orang. Hasil studi menunjukkan bahwa variabel spiritualitas kerja dan komitmen organisasi memiliki korelasi yang signifikan tinggi dengan nilai $r=0,813$. Maknanya bahwa spiritualitas yang dibangun atau dimiliki pengurus Jamaah Al-Khidmah Surabaya memiliki hubungan dengan ada atau tidaknya maupun tinggi dan rendahnya komitmen kerja pengurus di organisasi AlKhidmah.
\end{abstract}

Kata kunci: spiritualitas di tempat kerja, komitmen organisasi, organisasi dakwah

Spirituality and Organizational Commitment to Da'wah Organization. Abstract: Da'wah organization constitutes a non-profit organization which does not have financial purpose (financial benefit). Therefore, it does not uses financial instrument to empower its human resources. Workplace spirituality has become alternative way to move the human resources. The previous research in non-profit organization showed that workplace spirituality affects positively towards the employee's commitment in the organization. Meanwhile, organizational commitment has a significant influence towards performance and employee's loyalty to the organization. This study reveals about workplace spirituality in da'wah organization which does not involve financial instrument for moving it's employee. This research was especially conducted to the employee of Jamaah Al-Khidmah Surabaya. It is conducted on the basis theory of Workplace Spirituality pioneered by Milliman and friends and Organizational Commitment pioneered by Mowday and friends. It uses Spearman's associative correlation whose data were taken from the survey result of 19 people. This study results indicates that the variable of workplace spirituality and organizational commitment have highly significant correlation with $r$ $=0.813$. It means that spirituality built and owned by the employees of Jamaah AlKhidmah Surabaya has correlation to both the existence or not of and high or low level of work commitment of the employees in the organization.

Keywords: workplace spirituality, organizational commitment, da'wah organization 


\section{Pendahuluan}

Organisasi didefinisikan sebagai kumpulan orang yang ingin mencapai tujuan bersama. Dalam upaya mencapai tujuannya, organisasi akan senantiasa mengalami berbagai macam tantangan. Tantangan yang muncul dapat berasal dari dalam maupun luar organisasi. Organisasi yang mampu menghadapi tantangan-tantangan tersebut akan mampu berkembang dan bertahan. Beberapa faktor yang memengaruhi usaha organisasi untuk berkembang dan bertahan adalah peluang dan kinerja organisasi. ${ }^{1}$ Kinerja merupakan salah satu aspek utama yang butuh dicapai, karena meskipun ada peluang namun bila tidak diimbangi oleh kinerja yang baik, maka pertumbuhan organisasi akan terhambat. Oleh sebab itu, kinerja terbaik dari masing-masing individu dalam organisasi merupakan hal utama yang harus dicapai agar tujuan organisasi tercapai secara efektif dan efisien. ${ }^{2}$

Dalam upaya mencapai kinerja terbaik tersebut, organisasi laba maupun nirlaba akan menggunakan berbagai macam instrumen penggerakan sumber daya manusianya mulai dari instrumen yang bersifat materi (gaji, bonus, atau fee) maupun yang bersifat imateri (pujian, penghargaan, atau hadiah). Di awal perkembangan ilmu manajemen dan organisasi, instrumen materi berupa gaji merupakan instrumen penggerakan yang banyak digunakan oleh organisasi laba. Seiring berjalannya waktu pada akhir abad 20 para ilmuwan organisasi dan manajemen

\footnotetext{
${ }^{1}$ Leo Agung Manggala Yogatama dan Nilam Widyarini, "Kajian Spiritualitas di Tempat Kerja Pada Konteks Organisasi Bisnis." Jurnal Psikologi. Vol. 42, No. 1, (April 2015): 1-2.

2 Ibid.

3 Pawinee Petchsawang dan Dennis Duchon, "Measuring Workplace Spirituality in an Asian
}

menemukan bahwa manusia bekerja tidak hanya menggunakan tangan mereka tapi juga menggunakan hati dan jiwa mereka. ${ }^{3}$ Konsekuensi hal tersebut mereka tidak bisa memandang manusia hanya sebagai makhluk material yang hanya membutuhkan gaji tapi juga makhluk spiritual yang membutuhkan pekerjaan yang bermakna, yang pemenuhan kebutuhan keduanya harus seimbang. ${ }^{4}$ Pada studi yang telah dilakukan oleh Donde dan Dennis dalam Wen Sheng dan Chia Chen (tanpa tahun) menunjukkan bahwa pendekatan spiritualitas saat menjalankan pekerjaan di organisasi lebih efektif untuk menggerakkan sumber daya manusia, yang cara kerja motivasinya adalah menstimulasi kekuatan (motivasi) internal sumber daya manusia. ${ }^{5}$ Petchsawanga dan Duchon juga menjelaskan bahwa ketika manusia bekerja dengan keteguhan jiwa maka mereka akan menemukan beragam makna dan tujuan, serta beragam kepuasan akan pemenuhan kebutuhan, yang berarti tempat kerja akan menjadi tempat karyawan untuk mengekspresikan diri sepenuhnya dan menyeluruh. Ekspresi dari pengalaman akan kebermaknaan tersebut tidak hanya bisa mengurangi stress, konflik, dan kemangkiran kerja tapi juga meningkatkan performa kerja, perasaan nyaman, dan kualitas hidup mereka. ${ }^{6}$

Studi spiritualitas di tempat kerja sebagai instrumen penggerakan sumber daya manusia selama ini banyak dilakukan pada konteks organisasi laba dan organisasi

Context." Human Resource Development International. Vol. 12, No. 4, (September 2009): 459.

${ }^{4}$ Chieh Wen Sheng dan Ming Chia Chen, Workplace Spirituality Scale Design, 46.

5 lbid., 46.

6 Petchsawanga dan Duchon, "Measuring Workplace." 190-191. 
nirlaba jenis quasi-nonprofit organization, yaitu jenis organisasi nirlaba yang tidak hanya berorientasi melayani masyarakat tapi juga untuk mendapatkan keuntungan. ${ }^{7}$ Sedangkan penelitian hal yang sama pada konteks organisasi nirlaba jenis purenonprofit organization seperti organisasi dakwah belum pernah dilakukan. Organisasi nirlaba jenis pure-nonprofit organization adalah organisasi nirlaba yang murni berorientasi melayani masyarakat dan tidak ada orientasi mendapatkan keuntungan seperti quasi-nonprofit organization. ${ }^{8}$ Padahal antara organisasi nirlaba jenis purenonprofit dan quasi-nonprofit memiliki perbedaan yang cukup mendasar terutama dalam hal tujuan. Namun kedua tipe organisasi itu juga memiliki kebutuhan yang sama untuk meningkatkan kinerja pengurus organisasinya.

Organisasi dakwah sebagai jenis organisasi nirlaba jenis pure-nonprofit yang memiliki orientasi untuk memberikan pelayanan kepada umat dan tidak berusaha untuk mendapatkan keuntungan material, memiliki konsekuensi kondisi bahwa dana yang mereka miliki terbatas dan tidak pasti karena bergantung pada jumlah sumbangan atau hibah yang diterima. Oleh karena itu, pola penggerakan sumber daya manusia yang bertumpu pada instrumen material (gaji) sebagai instrumen penggerakan yang utama tidaklah disarankan. Drucker dalam Classic Drucker (2006) mengusulkan instrumen untuk menggerakkan pengurus organisasi nirlaba adalah dengan membangkitkan kepuasan/kebermaknaan (spiritual) pengurus terhadap pekerjaan yang mereka lakukan di organisasi. ${ }^{9}$

7 Mohamad M, Firma S, dan Heribertus Andre $\mathrm{P}$, Akuntansi Sektor Publik, (Yogyakarta: BPFE UGM, 2006), 4.
Sebagaimana definisi spiritualitas di tempat kerja yang telah disampaikan, usulan tersebut dapat ditafsirkan bahwa penerapan instrumen spiritual di tempat kerja untuk organisasi nirlaba itu lebih tepat dibandingkan dengan instrumen material.

Implikasi penerapan instrumen spiritual adalah ketidakpastian terpenuhinya kebutuhan material pengurus pada organisasi dakwah, mengingat pendapatan dana organisasi nirlaba yang terbatas dan tidak menentu. Pendapatan yang mereka dapatkan dari organisasi dakwah tempat mereka bekerja sangat terbatas, bahkan mungkin tidak ada. Oleh karenanya menjadi alamiah ketika pengurus organisasi dakwah akan mencari income lain diluar organisasinya. Adanya perilaku tersebut berpotensi memunculkan kondisi berkurangnya komitmen organisasi dari para pengurus di organisasi dakwah. Hal tersebut dikarenakan keanggotaan seseorang dalam organisasi menuntut komitmen (kesetiaan) orang tersebut pada organisasi tempat mereka berada. Jika seorang pengurus/karyawan mengikuti dua organisasi yang berbeda orientasi maka komitmen karyawan akan terbagi, sebab masing-masing organisasi yang diikuti pasti menuntut adanya komitmen.

Ancaman yang berpotensi muncul pada organisasi dakwah dengan adanya pengurus yang keanggotaannya terbagi pada dua atau lebih organisasi tersebut adalah ketika organisasi lain yang diikuti memiliki tujuan berbeda dengan organisasi dakwah mereka. Hal tersebut dapat mengancam komitmen pengurus di organisasi dakwah, karena

\footnotetext{
8 Ibid.

9 Peter F. Drucker, Classic Drucker (Jakarta: Bhuana IImu, 2006), 280.
} 
komitmen dan kinerjanya terbagi dengan organisasi lain. Organisasi dakwah dapat dijadikan sebagai kerja yang tidak prioritas (mudah ditinggalkan) dibanding kerja pada organisasi yang memberikan kepastian keuntungan finansial. Sehingga sesuai konteks organisasi dakwah, konsekuensi yang berpotensi muncul dengan penerapan instrumen spiritual tanpa dibarengi dengan instrumen material pada pengurusnya adalah menurunnya komitmen organisasi pengurus tersebut pada organisasinya. Namun ada fakta perilaku pengurus pada organisasi dakwah yang memiliki prestasi kerja yang cukup baik sebagai indikasi adanya komitmen organisasi yang cukup baik dalam menjalankan pekerjaannya, dengan asumsi pengurus tidak ada yang mendapatkan gaji maupun kompensasi material lain dari organisasi. Menurut pengakuan pengurus, pengurus menjalankan pekerjaan tersebut sematamata untuk mencari rida Allah dan balasan di akhirat (pemenuhan spiritual).

Organisasi dakwah tersebut adalah Jemaah Pengajian Al-Khidmah. Jemaah Al-Khidmah (JAK) Surabaya saat ini memiliki jumlah jemaah di wilayah Surabaya mencapai dua ribu orang untuk kegiatan pengajian yang diselenggarakan di tingkat kota dan kabupaten. Untuk jumlah jemaah di tingkat kecamatan ada sekitar lima ratus orang dan untuk jumlah jemaah di tingkat Indonesia bisa mencapai puluhan ribu orang. Jumlah jemaah tersebut menurut Ustaz Ali Mastur selaku Ketua JAK Surabaya juga terus mengalami peningkatan setiap tahunnya.

10 Ustaz Ali Mastur (Ketua JAK Surabaya Periode 20122016), Wawancara oleh Penulis, Surabaya 22 Agustus 2016.

11 David Priyasidharta, "Ribuan Jamaah Al Khidmah Kirim Fatihah untuk TK", diakses dari https://m.tempo.co/amphtml/read/news/2013/06/0
Beliau menyatakan bahwa untuk saat ini pengurus memang belum memiliki data pasti untuk jumlah jemaah tersebut namun pengurus mampu menyimpulkan bahwa jumlah jemaahnya meningkat setiap tahun, diketahui dari jumlah nasi bungkus yang disediakan untuk setiap kali pengadaan acara. ${ }^{10}$

Organisasi tersebut juga sering mendapatkan amanah untuk memimpin pengajian pada hajatan yang dilakukan oleh institusi pemerintah maupun swasta seperti even perayaan Hari Ulang Tahun (HUT) Kota Surabaya, HUT Propinsi Jawa Timur, HUT Perusahaan Daerah Air Minum (PDAM) Surabaya, dan HUT Universitas Airlangga (UNAIR) Surabaya. Fakta tersebut juga sejalan dengan berita yang disampaikan oleh Tempo pada hari Minggu tanggal 09 Juni 2013 yang menjelaskan bahwa ribuan anggota Jemaah Al-Khidmah Kota Surabaya mengirim doa dan pembacaan surah Alfatihah untuk almarhum Taufik Kiemas dan penutupan rangkaian acara peringatan hari jadi Kota Surabaya ke-720 di Taman Surya, di depan kantor Wali Kota Surabaya. 11

Jumlah jemaah yang dimiliki dan amanah yang didapatkan kepada pengurus JAK merupakan prestasi yang cukup patut untuk diperhitungkan, mengingat pengurus organisasi tersebut tidak mendapatkan kompensasi finansial selama menjalankan pekerjaannya. ${ }^{12}$ Adanya prestasi tersebut menunjukkan bahwa kinerja pengurus dalam menjalankan pekerjaannya cukup

9/078486824/ribuan-jamaah-al-khidmah-kirimfatihah-untuk-tk pada tanggal 24 Jul 2016 pukul 08.09. 12 Ustaz Ali Mastur (Ketua JAK Surabaya Periode 20122016), Wawancara oleh Penulis, Surabaya 22 Agustus 2016. 
baik. Hal ini menjadi indikasi bahwa komitmen pengurus untuk memajukan organisasinya juga cukup baik. Selain fakta tersebut diketahui juga bahwa pengurus masih bersedia menghadiri rapat meskipun larut malam dan fisik sudah cukup lelah setelah bekerja. Selama rapat berlangsung, mereka juga tetap bersemangat dan terlibat aktif dalam rapat tersebut. ${ }^{13}$ Beberapa pengurus bahkan ada yang rela menginap setiap malam di sekretariat Jemaah AlKhidmah Surabaya untuk menjaga sekretariat. ${ }^{14}$ Oleh karena adanya fakta pada pengurus Jemaah Al-Khidmah, tulisan ini bermaksud untuk melakukan studi lebih mendalam terhadap fenomena tersebut. Tujuannya untuk mengetahui apakah dengan adanya instrumen spiritual saja mampu menjadikan pengurus organisasi dakwah tetap memiliki komitmen untuk mencapai visi organisasinya.

Studi pada spiritualitas di tempat kerja dan komitmen organisasi yang pernah dilakukan adalah "Hubungan Spiritualitas Di Tempat Kerja (STK) Dengan Komitmen Organisasi Perawat Di RSI Fatimah Cilacap." Studi ini memiliki pandangan bahwa spiritualitas kerja merupakan penerapan praktik keagamaan dan spiritualitas perlu diakomodasi di tempat kerja bukan sekadar pengakuan terhadap legitimasinya tetapi juga pada proses kerja yang efektif dan efisien. Pandangan studi tersebut sama dengan studi ini yang memandang spiritualitas di tempat kerja sebagai hasil intervensi organisasi dalam rangka menumbuhkan dan meningkatkan motivasi. ${ }^{15}$ Hasil studi tersebut menunjukkan

13 Ibid.

14 Pemilik Warung Kopi Depan Sekretariat JAK Surabaya, Wawancara oleh Penulis, 18 Agustus 2016.

15 Wastu Adi Mulyono, "Hubungan Spiritualitas Di Tempat Kerja (STK) Dengan Komitmen Organisasi bahwa spiritualitas di tempat kerja terbukti memiliki hubungan bermakna dengan komitmen organisasi perawat. Hal tersebut berarti tingkat komitmen organisasi perawat RSI Fatimah Cilacap dipengaruhi oleh pengalaman spiritualitas dan nilai-nilai spiritualitas yang dirasakan oleh karyawannya. ${ }^{16}$ Namun RSI Fatimah sebagai subjek penelitian yang dilakukan oleh Wastu merupakan organisasi nirlaba yang termasuk dalam jenis quasi-nonprofit organization. Organisasi nirlaba jenis ini adalah jenis organisasi nirlaba yang memiliki tujuan tidak hanya untuk memberikan layanan kepada masyarakat tapi juga untuk mendapatkan keuntungan finansial dari usaha penyediaan/penjualan barang/jasa yang dilakukan.

Sedangkan subjek pada studi ini adalah organisasi dakwah yaitu organisasi nirlaba yang hanya berfokus pada pelayanan masyarakat tanpa ada tujuan untuk mendapatkan keuntungan finansial sama sekali. Sehingga subjek dalam kajian yang dilakukan oleh Wastu tidak menghadapi persoalan karyawan yang bekerja pada dua organisasi seperti yang dihadapi oleh subjek penelitian dalam kajian ini. Hal tersebut dikarenakan subjek dalam penelitian Wastu mendapatkan kompensasi finansial atas pekerjaannya sedangkan subjek pada penelitian ini tidak mendapatkan kompensasi tersebut. Berdasarkan penelitian tersebut, Wastu menemukan bahwa spiritualitas di tempat kerja karyawan pada RSI Fatimah memiliki hubungan dengan komitmen organisasi mereka pada tempat mereka bekerja. Namun mengingat adanya

Perawat Di RSI Fatimah Cilacap," (Tesis Magister Universitas Indonesia, tidak diterbitkan), 26. 16 Ibid., 101. 
perbedaan dinamika persoalan yang dihadapi oleh subjek penelitian pada studi yang dilakukan oleh Wastu dan studi ini maka masih butuh dilakukan studi lebih lanjut terhadap spiritualitas di tempat kerja apakah benar memiliki hubungan dengan komitmen organisasi pada konteks organisasi dakwah.

Studi lain yang telah dilakukan terhadap spiritualitas di tempat kerja "Workplace Spirituality and Employee Work Attitudes: An Exploratory Empirical Assessment" oleh Milliman, Czaplewski, dan Ferguson. Studi ini melibatkan responden dari berbagai organisasi, baik organisasi laba maupun nirlaba dengan tujuan untuk menemukan hubungan spiritualitas kerja SDM terhadap lima sikap kerja mereka dalam organisasi yaitu komitmen organisasi, keinginan untuk berhenti, kepuasan kerja, keterlibatan kerja, dan OBSE (Organization Based Self Esteem). ${ }^{17}$ Hasil studi tersebut menunjukkan bahwa spiritualitas di tempat kerja memiliki hubungan yang signifikan terhadap lima sikap kerja tersebut. Dalam studi tersebut, Milliman, Czaplewski, dan Ferguson memandang bahwa motivasi spiritual sebagai motivasi bawaan masing-masing individu dalam organisasi. Sehingga tanpa adanya intervensi untuk menumbuhkan motivasi tersebut, individu dalam organisasi sudah memiliki motivasi spiritual sendiri. Pandangan ini berbeda dengan studi yang dilakukan di sini. Pada studi ini memandang bahwa adanya spiritualitas pada karyawan/pengurus dalam organisasi itu disebabkan oleh adanya intervensi dari organisasi tersebut. Sehingga ketika ada

\footnotetext{
17 John Milliman, Andrew J. Czaplewski dan Jeffery Ferguson, "Workplace Spirituality and Employee Work Attitudes: An Exploratory Empirical Assessment."
}

karyawan/pengurus tertentu yang sebelum masuk organisasi tersebut memiliki sisi spiritual rendah maka seiring berjalannya waktu dengan intervensi yang dilakukan oleh organisasi, derajat spiritualnya bisa meningkat.

Sehingga berdasarkan asumsi-asumi penelitian yang telah dilakukan, belum ada penelitian yang benar-benar menjawab persoalan spiritualitas di tempat kerja yang berhubungan dengan komitmen organisasi dengan konteks pada organisasi dakwah. Oleh karenanya, penting untuk dilakukan studi lebih spesifik terhadap hubungan penerapan spiritualitas di tempat kerja dengan komitmen organisasi pada pengurus di organisasi dakwah. Adanya studi ini diharapkan mampu melengkapi khazanah ilmu dalam bidang manajemen dan organisasi khususnya pada aspek membangun komitmen organisasional dan spiritualitas di tempat kerja.

\section{Spiritualitas di Tempat Kerja}

Spiritualitas di tempat kerja didefinisikan oleh Jurkiewicz dan Giacalone sebagai reinforcing the employees' transcendental experience through works (penguatan pengalaman transenden karyawan melalui pekerjaan yang dijalani)..$^{18}$ Claude and Zamor mengusulkan arti spiritualitas di tempat kerja yaitu penemuan individu akan makna hidup yang lebih dalam dan pekerjaan yang bernilai melalui refleksi diri dan hubungan kerja di tempat kerja, termasuk hubungan dengan orang lain, perwujudan nilai-nilai

Journal of Organizational Change Management. Vol. 16 No. 4, (2003): 426-447.

18 Wen Sheng dan Chia Chen, "Workplace Spirituality.," 48. 
moral, dan kepedulian terhadap dunia. ${ }^{19}$ Dari beberapa definisi tersebut dapat diketahui bahwa spiritualitas di tempat kerja adalah perasaan bermakna seseorang pada pekerjaan yang dilakukan di tempat kerjanya. Kebermaknaan tersebut bisa muncul dari refleksi diri individu atas nilai pekerjaan yang dilakukan, interaksi dengan rekan kerja, perwujudan nilai-nilai karyawan tersebut di tempat kerja, dan adanya kepedulian karyawan terhadap persoalan yang terjadi di dunia.

Milliman, dkk. dalam kajian yang dilakukan menjelaskan bahwa manusia sebagai individu yang memiliki kebutuhan spiritual tidak hanya butuh akomodasi dari organisasi terhadap kebutuhan tersebut. Namun lebih dari itu yaitu pekerjaan yang bermakna bagi individu tersebut. Sehingga spiritualitas individu tersebut tidak hanya terpenuhi dengan adanya dukungan dari lingkungan kerja tapi juga senantiasa terpelihara karena perasaan bermakna pada pekerjaan di tempat kerjanya. Sehingga sudut pandang untuk menilai dan mengukur spiritualitas karyawan di tempat kerja ada tiga yaitu karyawan sebagai individu, karyawan sebagai anggota kelompok, dan karyawan sebagai anggota organisasi. Berdasarkan tiga sudut pandang tersebut terdapat tiga dimensi dalam teori spiritualitas di tempat kerja yaitu meaningful work (level individu), sense of community (level kelompok), dan alignment with the organization's values (level organisasi)..$^{20}$

Meaningful work (kebermaknaan terhadap pekerjaan) adalah aspek fundamental dalam spiritualitas di tempat kerja yang melibatkan

19 Ibid.

20 Milliman, Czaplewski dan Ferguson, "Workplace Spirituality.," 428. perasaan mendalam dan tujuan seseorang dalam melakukan suatu pekerjaan. Dimensi ini merepresentasikan bagaimana karyawan berinteraksi dengan aktivitasnya sehari-hari dalam sudut pandang personal. Ekspresi spiritualitas di tempat kerja ini mengasumsikan bahwa setiap orang memiliki motivasi internal, kebenaran yang diyakini, dan hasrat untuk terlibat dalam aktivitas yang memberikan makna yang lebih besar dalam hidup mereka dan hidup orang lain. ${ }^{21}$

Community (kelompok) adalah dimensi yang kritis dalam spiritualitas di tempat kerja yang melibatkan perasaan memiliki koneksi yang mendalam dan relasi dengan orang lain yang disebut dengan sense $o$ community (perasaan terhubung dengan kelompok). Dimensi ini terdapat pada perilaku manusia ketika berada dalam kelompok dan menyangkut interaksi antara karyawan dengan teman kerja. ${ }^{22}$

Alignment with organizational values (penyelarasan sikap dengan nilai-nilai organisasi) adalah dimensi yang ketiga dari spiritualitas di tempat kerja. Dimensi ini menjelaskan tentang pengalaman individu terhadap perasaan kuat atas keselarasan keyakinan personal dengan tujuan (purpose) dan misi organisasi tempat mereka bekerja. Komponen dari dimensi ini meliputi interaksi karyawan dengan tujuan organisasi yang lebih besar. Penyelarasan sikap dengan nilainilai organisasi ini juga merujuk pada premis bahwa individu memiliki tujuan yang lebih besar dari dirinya sendiri dan harus memberikan kontribusi kepada orang lain dan masyarakat. ${ }^{23}$

\footnotetext{
21 Ibid., 429.

22 Ibid., 429.

23 lbid., 430
} 
Dalam studi ini, untuk mengukur tingkat spiritualitas di tempat kerja subjek penelitian, ketiga dimensi di atas akan menjadi pijakan dalam pengukuran.

\section{Komitmen Organisasi}

Menurut Gibson, komitmen organisasi adalah identifikasi, keterlibatan, dan loyalitas yang diekspresikan oleh seseorang terhadap organisasinya. ${ }^{24}$ Sedangkan Philip dalam Luthans menyatakan bahwa komitmen organisasi adalah kekuatan identifikasi individual secara relatif dan keterlibatannya dalam organisasi tertentu. ${ }^{25}$ Berdasarkan gagasan dari Mowday, Porter, dan Steers diketahui bahwa komitmen organisasi adalah The relative strength of an individual's identification with and involvement in a particular organization (Kekuatan relatif dari identifikasi individu terhadap dan keterlibatannya pada organisasi tertentu). Definisi tersebut menunjukkan bahwa komitmen organisasi memiliki arti lebih dari sekadar loyalitas yang pasif, tetapi melibatkan hubungan aktif dan keinginan karyawan untuk memberikan kontribusi yang berarti pada organisasinya. Oleh sebab itu, untuk meninjau komitmen organisasi tidak hanya bisa disimpulkan dari ekspresi kepercayaan dan pendapat individu terhadap organisasi, tapi juga dari kontribusi yang dilakukan untuk organisasi. ${ }^{26}$

Secara lebih detil Mowday dkk menjelaskan bahwa komitmen organisasi dapat dicirikan dari tiga faktor yaitu: (a) kepercayaan yang

\footnotetext{
${ }^{24}$ Gibson, J.L. et. all. Organization Behavior: Structure and Processes, (8th ed), (USA: Business Publication, Inc. 1996).

25 Luthans, F. Organizational Behavior. 7th Edition, (New York: McGraw Hill International, 1996).
}

kuat dan penerimaan terhadap tujuan serta nilai organisasi; (b) kesediaan untuk menggunakan seluruh usaha demi kepentingan organisasi; (c) keinginan kuat untuk mempertahankan keanggotaan di organisasi. Definisi ini mempertegas pengertian bahwa komitmen organisasi tidak hanya berupa niat seseorang untuk mewujudkan nilai-nilai dan tujuan organisasi tapi juga ada usaha (daya upaya) untuk mengaktuskan niat tersebut dalam kehidupan nyata sehingga terwujud dalam sebuah perilaku tertentu.

Secara umum dalam pengukuran komitmen organisasi, ada dua teknik pengukuran yang sering digunakan dalam kajian-kajian komitmen organisasi yaitu Organizational Commitment Questionnaire (OCQ) yang dirancang oleh Mowday, Steers, dan Porter dan Three-Component Organizational Commitment Scale yang dirancang oleh Allen and Meyer. Menurut kajian yang dilakukan oleh ASQ (American Society for Quality), penggunaan alat pengukuran komitmen tersebut bergantung pada kebutuhan manajemen. Jika manajemen ingin mengetahui tingkat penerimaan karyawan terhadap tujuan organisasi, kesediaan karyawan bekerja keras untuk organisasi, dan keinginan (desire) karyawan untuk tetap tinggal di organisasi maka OCQ lebih tepat untuk mengukur komitmen karyawan. Jika manajemen ingin mengetahui tingkat komitmen karyawan pada level komitmen afektif, komitmen lanjutan, dan komitmen normatif maka Three-Component Organizational Commitment Scale lebih tepat digunakan untuk mengukur komitmen

\footnotetext{
${ }^{26}$ Richard T. Mowday, Richard M. Steers, dan Lyman W. Porter, "The Measurement of Organizational Commitment," Journal of Vocational Behavior, Vol. 14, (1979): 226.
} 
karyawan. ${ }^{27}$ Pada studi ini yang menjadi fokus pembahasan adalah tingkat komitmen dalam sudut pandang: (a) penerimaan karyawan terhadap tujuan organisasi; (b) kesediaan karyawan bekerja keras untuk organisasi; dan (c) keinginan (desire) karyawan untuk tetap tinggal di organisasi karena organisasi yang menjadi subjek penelitian dalam penelitian ini adalah organisasi pure-nonprofit yang tidak memberikan imbalan finansial kepada karyawannya sebagai balas jasa atas pekerjannya sehingga kemungkinan adanya komitmen pada level lanjutan itu kecil bahkan tidak ada. Maka dari itu, alat ukur yang dikembangkan oleh Mowday, Steers, and Porter yang lebih tepat digunakan dalam studi ini.

\section{Metodologi}

Studi ini berdasarkan riset tipe korelasi (correlation research). Faktor yang hendak diketahui hubungannya adalah spiritualitas di tempat kerja dan komitmen organisasi pada pengurus jemaah Al-Khidmah Surabaya. Jumlah anggota pada subjek yang diteliti adalah total anggota atau populasi. Populasi dalam studi ini ada 19 anggota dengan kriteria yang semuanya berjenis kelamin laki-laki. Dalam studi ini spiritualitas di tempat kerja sebagai variabel independen (bebas) dan komitmen organisasi sebagai variabel dependen (terikat) dalam penelitian ini. Variabel independen (bebas) adalah variabel yang memengaruhi atau menjadi penyebab perubahan pada variabel dependen (terikat). ${ }^{28}$ Sedangkan variabel

27 Becky J. Starnes dan Stephen A. Truhon, "A Primer on Organizational Commitment." Human Development and Leadership Division, 4-5.

28 Masyhuri dan M. Zainuddin, Metode Penelitian Pendekatan Praktis dan Aplikatif (Bandung: Refika Aditama, 2009), 123. dependen (terikat) adalah variabel yang dipengaruhi atau menjadi akibat dari variabel independen (bebas). ${ }^{29}$ Dengan hipotesis bahwa $\mathrm{H}_{1}=$ spiritualitas di tempat kerja memiliki hubungan signifikan dengan komitmen organisasi.

Definisi operasional dari spiritualitas di tempat kerja adalah perasaan bermakna seorang karyawan dikarenakan pekerjaan yang dilakukannya di tempat kerja. Untuk mengukur tingkat spiritualitas di tempat kerja pada subjek studi dikembangkan instrumen dari hasil penelitian yang dilakukan oleh Milliman, Czaplewski and Ferguson. Atribut yang ingin diketahui dari variabel spiritualitas di tempat kerja adalah rendah, sedang, atau tinggi pada subjek studi. Maka dari itu, skala pengukuran yang digunakan adalah skala Likert yang mampu mengukur tingkatan sikap dari subjek penelitian yang diteliti. ${ }^{30}$ Dimensi pada variabel spiritualitas di tempat kerja terdiri dari tiga dimensi yaitu kebermaknaan terhadap pekerjaan, perasaan terhubung dengan kelompok, penyelarasan sikap dengan nilai-nilai organisasi. ${ }^{31}$

Kebermaknaan terhadap pekerjaan memiliki indikator yaitu pertama, merasa terdorong menjalankan tugas dari Al-Khidmah karena perilaku tersebut bernilai kebenaran; kedua, merasa hidupnya bermanfaat dengan menjalankan tugas dari Al-Khidmah; ketiga, merasa tugas yang dilakukan di Al-Khidmah merupakan hal penting untuk dilakukan selama hidupnya.

\footnotetext{
${ }^{29}$ Ibid.

${ }^{30}$ Sugiyono, Metode Penelitian Kuantitatif, Kualititatif, dan R\&D (Bandung: Alfabeta, 2015), 93.

31 Milliman, Czaplewski dan Ferguson, "Workplace Spirituality.," 429-430.
} 
Perasaan terhubung dengan kelompok memiliki indikator yaitu pertama, pengurus merasa bahwa mereka yang ada di jemaah Al-Khidmah merupakan saudara karena sama-sama memiliki visi mengabdi di AlKhidmah; kedua, antar pengurus merasa perlu untuk saling membantu dalam menjalankan tugas dari Al-Khidmah; ketiga, antar pengurus merasa memiliki kepedulian untuk saling membantu menjalankan tugas maupun membantu sebagai saudara seperjuangan.

Penyelarasan sikap dengan nilai-nilai organisasi memiliki indikator yaitu pertama, pengurus memandang menjalankan tugas dari Al-Khidmah merupakan bagian dari tujuan hidupnya; kedua, pengurus memandang menjalankan tugas dari AlKhidmah lebih utama dibandingkan dengan kegiatan pribadinya; ketiga, pengurus memandang harus memberikan kontribusi yang optimal untuk pengabdiannya kepada Al-Khidmah; keempat, pengurus percaya pemimpin organisasi JAK Surabaya mampu membimbing anggota-anggotanya menyukseskan visi organisasi Al-Khidmah.

Indikator-indikator dimensi spiritualitas di tempat kerja di atas dikembangkan dengan prosedur yaitu pertama memahami realitas yang dimaksud dalam masing-masing dimensi; kedua menyusun indikasi-indikasi kondisi yang seharusnya terjadi agar maksud dalam dimensi tersebut terwujud sesuai dengan konteks subjek penelitian, dan terakhir melakukan uji validitas indikator kepada ahli serta melakukan evaluasi sesuai dengan saran ahli sebelum kisi-kisi instrumen diuji dalam software SPSS.

32 Ibid.
Definisi operasional dari komitmen organisasi adalah sikap dari pengurus organisasi yang menerima dan bersedia mewujudkan nilai-nilai serta tujuan organisasinya melalui upaya mempertahankan keanggotaanya di organisasinya serta usaha-usaha yang dibutuhkan untuk kepentingan organisasinya. Untuk mengukur tingkat komitmen organisasi subjek penelitian dikembangkan instrumen komitmen organisasi dari hasil penelitian Mowday, Porter, dan Steers tahun 1979 dalam jurnal The Measurement of Organizational Commitment. Atribut yang ingin diketahui dari variabel komitmen organisasi adalah rendah, sedang, atau tinggi komitmen organisasi pada subjek penelitian. Maka dari itu, skala pengukuran yang digunakan adalah skala Likert yang mampu mengukur tingkatan sikap dari subjek penelitian yang diteliti. ${ }^{32}$ Variabel komitmen organisasi memiliki tiga dimensi yaitu kepercayaan kepada organisasi, kesediaan berkorban untuk organisasi, dan keinginan untuk bertahan di organisasi. ${ }^{33}$

Kepercayaan kepada organisasi memiliki indikator: (a) pengurus memiliki tujuan yang sama dengan Al-Khidmah yaitu mewujudkan generasi saleh-salihah dengan pedoman ajaran tarekat Qadiriyah Wa Naqsabandiyah Al-Usmaniyah; (b) pengurus memiliki keyakinan bahwa nilai-nilai yang diajarkan oleh tarekat Qadiriyah Wa Naqsabandiyah Al-Usmaniyah merupakan nilai-nilai yang benar; (c) pengurus sepakat dengan program-program Al-Khidmah (seperti: majelis zikir, majelis khataman Alquran, majelis selawat kepada Rasul, majelis haul, majelis manaqib, majelis doa bersama,

33 Mowday, Steers, dan Porter, "The Measurement of.," 226. 
kegiatan wiridan serta berdoa setelah salat, dan menjenguk anggota organisasi yang sedang sakit); (d) pengurus setuju pada aturan-aturan yang dibuat Al-Khidmah (seperti: membayar iuran bulanan/mingguan, menaati perintah pemimpin, dan melakukan wirid dan doa setelah salat); (e) pengurus merasa bangga menjadi anggota organisasi Al-Khidmah.

Kesediaan berkorban untuk organisasi memiliki indikator: (a) pengurus bersedia melaksanakan setiap tugas yang diamanahkan oleh Al-Khidmah; (b) pengurus selalu berusaha untuk menjalankan tugas dari Al-Khidmah melebihi standar pengerjaan tugas tersebut; (c) pengurus bersedia menjalankan tugas tambahan di luar tugas intinya, seperti menjalankan tugas pengurus lain yang berhalangan demi tercapainya target program organisasi.

Keinginan untuk bertahan di organisasi memiliki indikator: (a) pengurus lebih memilih untuk tetap menjadi anggota organisasi Al-Khidmah, apapun hambatan yang terjadi; (b) pengurus lebih memilih mengorbankan kepentingan pribadi dari pada harus keluar dari Al-Khidmah.

Metode pengambilan data menggunakan angket. Asumsinya subjek penelitian merupakan orang yang paling memahami dirinya sendiri, dapat memahami instrumen pernyataan/pertanyaan peneliti sesuai dengan pemahaman peneliti, dan dapat diajak kerjasama melaporkan kondisi dirinya dengan jujur. ${ }^{34}$ Uji validitas instrumen dilakukan dengan validitas isi dan validitas statistik. Untuk mengukur hasil validitas

34 Sutrisno Hadi, Metodologi Research, Jilid I (Yogyakarta: Yayasan Penerbit Fakultas Psikologi UGM, 1984), 157 yang telah dilakukan oleh expert judgment, menggunakan koefisien validitas isi yang diusulkan oleh Aiken. Kemudian instrumen diuji kembali melalui uji statistik pada software SPSS versi 20.0 yang berdasarkan pada rumus pearson product moment. Uji reliabilitas instrumen dilakukan teknik Internal consistency, menggunakan rumus Alpha Cronbach pada software SPSS versi 20.0. Hasil akhir dari pengujian validitas kuesioner adalah 49 instrumen valid, dengan rincian 21 instrumen valid dengan nilai reliabilitas 0,934 yang berasal dari kuesioner variabel spiritualitas di tempat kerja dan 28 instrumen valid dengan nilai reliabilitas 0,947 yang berasal dari kuesioner komitmen organisasi. Hal tersebut menunjukkan bahwa tingkat keterandalan atau reliabilitas kuesioner dalam penelitian ini juga tinggi.

Teknik analisis data dilakukan dua tahap yaitu deskripsi data dan analisis data. Tahap deskripsi data dilakukan untuk mengetahui tingkat spiritualitas kerja dan komitmen organisasi masing-masing subjek penelitian baru setelah itu dilakukan analisis korelasi terhadap data dengan teknik korelasi tata jenjang atau rank-order correlation atau juga biasa disebut uji korelasi Spearman. Korelasi tata jenjang adalah uji korelasi yang digunakan untuk menentukan hubungan dua gejala yang kedua-duanya merupakan gejala ordinal atau tata jenjang, serta memiliki jumlah anggota sampel penelitian kurang dari $30 .{ }^{35}$

\footnotetext{
35 Suharsimi Arikunto, Prosedur Penelitian Suatu Pendekatan Praktik, (Jakarta: Rineka Cipta, 2010), 316, 321.
} 


\section{Profil Singkat Jemaah Al- Khidmah}

Jemaah Al-Khidmah merupakan perkumpulan yang menaungi kegiatan tarekat Qadiriyah Wa Naqsabandiyah AlUsmaniyah. Organisasi ini didirikan untuk membantu penyelenggaraan kegiatan tarekat dan sebagai kepanjangan tangan guru tarekat dalam mendakwahkan nilainilai tarekat Qadiriyah Wa Naqsabandiyah Al-Usmaniyah. Organisasi ini didirikan oleh K.H. Ahmad Asrori Al Ishary selaku guru besar tarekat Qadiriyah Wa Naqsabandiyah Al-Usmaniyah pada 25 Desember 2005. Sebelum mendeklarasikan Al-Khidmah menjadi organisasi, Kiai Asrori telah membuat suatu buku berjudul Pedoman Kepemimpinan dan Kepengurusan dalam Kegiatan dan Amaliah At-Tarekat dan AlKhidmah. Buku tersebut dibuat untuk menyistematisasikan serta memberikan pijakan yang jelas untuk pelaksanaan seluruh kegiatan tarekat yang didakwahkan oleh Kiai Asrori. ${ }^{36}$ Jemaah Al-Khidmah memiliki visi untuk mewujudkan generasi yang saleh salihah sejahtera lahir dan batin, yang pandai bersyukur, dapat menyenangkan hati keluarganya, orang tuanya, guru-gurunya hingga Nabi Besar Muhammad saw. sesuai dengan petunjuk Alquran dan hadis serta tuntunan akhlak para assalafussoleh.

Sesuai dengan buku Pedoman Kepemimpinan dan Kepengurusan dalam Kegiatan dan Amaliah At-Tarekat dan AlKhidmah, diketahui bahwa kegiatan utama Al-Khidmah adalah berzikir dan berdoa kepada Allah SWT. Namun kegiatan zikir dan

36 Moch. Dony Dermawan, "Sejarah Lahir dan Berkembangnya Perkumpulan Jama'ah Al Khidmah dalam Menyiarkan Ajaran-Ajaran K.H. Ahmad Asrori Al-Ishaqy di Kecamatan Kenjeran Kota Surabaya Pada Tahun 2005-2014," (Skripsi Sarjana UIN Sunan Ampel Surabaya), 46. berdoa tersebut dikategorikan lagi berdasarkan tujuan doa tersebut dipanjatkan dan jumlah peserta dalam majelis zikir tersebut. Sehingga terbagi beberapa jenis majelis zikir yaitu majelis mubaya'ah, majelis khushusy, majelis khushusy kubro, majelis zikir, ta'lim, majelis haul, majelis haul akbar.

Kepengurusan dalam jemaah Al-Khidmah terbagi menjadi dua yaitu pengurus Thoriqoh dan pengurus Al-Khidmah. Pengurus Thoriqoh adalah para murid yang telah dipilih dan ditetapkan oleh rapat para murid dan disampaikan kepada Guru Thoriqoh, yang bertugas untuk mengurus kegiatan amaliah Thoriqoh. Sedangkan pengurus AlKhidmah adalah anggota Al-Khidmah yang telah dipilih dan ditetapkan oleh rapat AlKhidmah, yang bertugas untuk memfasilitasi terselenggaranya kegiatan dan amaliah yang telah ditetapkan dan diamalkan oleh Guru Thoriqoh atau para ulama assalafussoleh, dan para pinisepuh pendahulu kita ${ }^{37}$. Subjek studi ini adalah pengurus Al-Khidmah pada jemaah Al-Khidmah di tingkat kota Surabaya.

\section{Hasil Pengukuran Tingkat Spiritualitas Kerja dan Komitmen Organisasi}

Hasil dari pengukuran melalui kuesioner didapatkan total skor responden untuk variabel spiritualitas di tempat kerja adalah sebagai berikut:

${ }^{37}$ Achmad Asrory Al Ishaqy, Pedoman Kepemimpinan dan Kepengurusan Dalam Kegiatan dan Amaliah AthThoriqoh dan Al-Khidmah (Semarang : Jamaah Al Khidmah, 2006), 6. 
Tabel 1 - Hasil Pengukuran Tingkat Spiritualitas Kerja Pengurus Al-Khidmah

\begin{tabular}{c|c|c|c}
\hline Kategorisasi & Skor & $\boldsymbol{\Sigma}$ & $\%$ \\
\hline Rendah & $<42$ & 4 & $21 \%$ \\
Sedang & $42-65$ & 12 & $63 \%$ \\
Tinggi & $>65$ & 3 & $16 \%$ \\
\hline \multicolumn{2}{c|}{ Total } & $\mathbf{1 9}$ & $\mathbf{1 0 0 \%}$ \\
\hline
\end{tabular}

Berdasarkan tabel di atas diketahui bahwa ada 12 responden yang memiliki tingkat spiritualitas kerja sedang, 4 responden dengan tingkat spiritualitas rendah, dan 3 responden dengan tingkat spiritualitas tinggi. Berdasarkan tabel tersebut juga diketahui bahwa mayoritas responden dalam penelitian ini memiliki tingkat spiritualitas sedang yakni sebanyak $63 \%$ sedangkan sisanya memiliki tingkat spiritualitas rendah dengan persentase $21 \%$ dan tinggi dengan persentase $16 \%$. Hasil ini sejalan dengan fakta yang ditemukan bahwa pengurus cenderung memiliki kebermaknaan yang kuat terhadap pekerjaan yang mereka lakukan untuk AlKhidmah. Terbukti menurut hasil studi ini hanya ada $21 \%$ pengurus yang tingkat spiritualitas kerjanya rendah, sedangkan 79\% lainnya memiliki tingkat spiritualitas kerja yang sedang dan tinggi.

Hasil dari pengukuran melalui kuesioner didapatkan total skor masing-masing responden untuk variabel komitmen organisasi adalah sebagai berikut:
Tabel 2. Hasil Pengukuran Tingkat Komitmen Organisasi Pengurus Al-Khidmah

\begin{tabular}{c|c|c|c}
\hline Kategori & Skor & $\boldsymbol{\Sigma}$ & $\%$ \\
\hline Rendah & $<61$ & 3 & $16 \%$ \\
Sedang & $61-93$ & 11 & $58 \%$ \\
Tinggi & $>93$ & 5 & $26 \%$ \\
\hline \multicolumn{2}{c|}{ Total } & 19 & $\mathbf{1 0 0 \%}$ \\
\hline
\end{tabular}

Dari tabel di atas diketahui bahwa responden yang memiliki tingkat komitmen organisasi yang rendah ada 3 orang dengan persentase $16 \%$, responden yang memiliki tingkat komitmen organisasi yang sedang ada 11 orang dengan persentase $58 \%$, dan responden yang memiliki tingkat komitmen organisasi yang tinggi ada 5 orang dengan persentase $26 \%$. Hasil studi ini sejalan dengan fakta yang ditemukan di lapangan bahwa hanya ada sedikit pengurus yang komitmen organisasinya rendah dengan indikasi pengurus yang ingin keluar dari organisasi menurut Ketua Al-Khidmah. Dalam studi ini diketahui bahwa pengurus dengan tingkat komitmen organisasi yang rendah adalah $16 \%$ yang secara persentase statistik tidak jauh berbeda dengan perkiraan Ketua Al-Khidmah.

\section{Hasil Pengukuran Korelasi Spiritualitas di Tempat Kerja dengan Komitmen Organisasi}

Hasil perhitungan korelasi menggunakan rumus korelasi Spearman melalui software SPSS versi 20.0 diketahui sebagai berikut: 
Tabel 3 - Hasil Perhitungan Hubungan Variabel Spiritualitas di Tempat Kerja dan Komitmen

\begin{tabular}{c|c|c}
\multicolumn{3}{|c}{ Organisasi } \\
\hline $\begin{array}{c}\text { Koefisien } \\
\text { Korelasi } \\
\text { Variabel }\end{array}$ & $\begin{array}{c}\text { Spiritualitas } \\
\text { di Tempat } \\
\text { Kerja }\end{array}$ & $\begin{array}{c}\text { Komitmen } \\
\text { Organisasi }\end{array}$ \\
\hline $\begin{array}{c}\text { Spiritualitas di } \\
\text { Tempat Kerja }\end{array}$ & 1 & 0,813 \\
$\begin{array}{c}\text { Komitmen } \\
\text { Organisasi }\end{array}$ & 0,813 & 1 \\
\hline
\end{tabular}

Diketahui pada tabel 3, bahwa nilai $r$ adalah 0,813 . Nilai $r$ tersebut menunjukkan bahwa hubungan antara variabel spiritualitas kerja dan komitmen organisasi adalah signifikan tinggi. Nilai $r$ pada hasil perhitungan korelasi variabel spiritualitas kerja dan komitmen organisasi juga bernilai positif (+). Hasil perhitungan hubungan dua variabel spiritualitas kerja dan komitmen organisasi ini menunjukkan bahwa kenaikan variabel spiritualitas kerja akan diikuti dengan kenaikan variabel komitmen organisasi. Dengan adanya nilai $r$ yang tinggi maka potensi adanya kenaikan variabel spiritualitas kerja terhadap komitmen organisasi juga semakin tinggi.

Nilai $r=0,813$, hal itu berarti adanya komitmen organisasi para pengurus yang cukup kuat itu berhubungan dengan adanya spiritualitas yang cukup kuat. Terbukti dalam studi ini bahwa tingkat spiritualitas kerja pengurus mayoritas termasuk dalam kategori tinggi dan sedang dengan persentase $79 \%$.

\section{Kesimpulan}

Berdasarkan hasil analisis di atas diketahui bahwa spiritualitas kerja pengurus di AlKhidmah mayoritas berada pada kategori sedang dengan persentase $63 \%$. Sedangkan sisanya berada pada kategori rendah sebesar $21 \%$ dan tinggi sebesar 16\%. Pada studi pendahuluan yang dilakukan ada pengakuan dari salah satu pengurus organisasi bahwa pengurus menjalankan pekerjaan tersebut semata-mata untuk mencari rida Allah dan balasan di akhirat. Adanya keyakinan pengurus tersebut ternyata terbukti secara empiris, dengan hasil pengukuran spiritualitas di tempat kerja pengurus mayortitas di tingkat sedang bahwa hal tersebut menjadi salah satu pendorong terbesar mereka dalam menyelesaikan pekerjaan-pekerjaan yang diamanahkan oleh organisasinya.

Untuk hasil analisis variabel komitmen organisasi diketahui bahwa mayoritas pengurus Al-Khidmah memiliki tingkat komitmen organisasi sedang dengan persentase $58 \%$. Sedangkan untuk sisa $16 \%$ pengurus memiliki tingkat komitmen rendah dan $26 \%$ pengurus memiliki tingkat komitmen tinggi. Hasil pengukuran komitmen kerja ini menjadi afirmasi terhadap pengakuan yang disampaikan oleh ketua Al-Khidmah bahwa pengurus masih bersedia menghadiri rapat meskipun larut malam dan fisik sudah cukup lelah setelah bekerja. Selama rapat berlangsung, mereka juga tetap bersemangat dan terlibat aktif dalam rapat tersebut. Beberapa pengurus bahkan ada yang rela menginap setiap malam di sekretariat JAK Surabaya untuk menjaga sekretariat. Adanya usaha-usaha tersebut menunjukkan bahwa mereka memiliki komitmen terhadap terwujudnya tujuan organisasi mereka, yang hal tersebut selaras dengan hasil studi yang menunjukkan tingkat komitmen organisasi pengurus mayoritas sedang. 
Berdasarkan hasil analisis hubungan kedua variabel dalam studi ini dapat disimpulkan bahwa variabel spiritualitas kerja memiliki hubungan yang tinggi dengan komitmen organisasi dengan tingkat signifikansi korelasinya sebesar $r \quad 0,813$. Hubungan kedua variabel tersebut juga positif. Hal tersebut bermakna bahwa ketika ada kenaikan pada variabel spiritualitas kerja maka variabel komitmen kerja juga akan mengalami kenaikan. Kesimpulan ini sesuai dengan hipotesis bahwa $\mathrm{H}_{1}=$ spiritualitas di tempat kerja memiliki hubungan signifikan dengan komitmen organisasi. Hasil studi ini menunjukkan bahwa prestasi kerja yang diraih oleh pengurus Al-Khidmah karena adanya niat untuk mendapatkan rida Allah (spiritual), yang hal tersebut selaras dengan adanya komitmen mereka juga dalam menjalankan pekerjaan dalam kepengurusan. Sehingga ketika niat mereka untuk mendapatkan rida Allah semakin besar maka kemungkinan munculnya perilaku untuk menjalankan pekerjaan dari organisasi juga semakin tinggi. Selain itu, hasil studi ini juga menunjukkan bahwa penerapan spiritualitas di tempat kerja pada organisasi dakwah ternyata memiliki hasil yang sama sebagaimana yang terjadi pada organisasi laba. Meskipun dalam konteks organisasi dakwah Al-Khidmah pengurus murni mendapatkan pemeliharaan spiritualitas di tempat kerja saja tanpa ada dukungan material dari organisasi. Oleh karena itu, hasil penelitian ini bisa menjadi masukan untuk organisasi dakwah yang lain dalam mempertahankan komitmen organisasi pengurusnya. Bahwa untuk meningkatkan dan menjaga komitmen karyawan tidak hanya dapat dilakukan dengan instrumen finansial namun juga instrumen spiritual yang mana lebih sesuai dengan kondisi organisasi dakwah.

\section{Bibliografi}

Al-Ishaqy, Achmad Asrory. Pedoman Kepemimpinan dan Kepengurusan Dalam Kegiatan dan Amaliah Ath Thoriqoh dan Al-Khidmah. Semarang: Jamaah Al-Khidmah, 2006.

Arikunto, Suharsimi. Prosedur Penelitian Suatu Pendekatan Praktik. Jakarta: Rineka Cipta, 2010. Dermawan, Moch. Dony. "Sejarah Lahir dan Berkembangnya Perkumpulan Jama'ah Al-Khidmah Dalam Menyiarkan Ajaran-Ajaran KH. Ahmad Asrori Al-Ishaqy di Kecamatan Kenjeran Kota Surabaya Pada Tahun 2005-2014." Sarjana, UIN Sunan Ampel Surabaya, 2016.

Drucker, Peter F. Classic Drucker. Jakarta: Bhuana IImu, 2006.

Gibson, J.L. at. All. Organization Behavior: Structure and Processes, (8th ed). USA: Business Publication, Inc, 1996.

Luthans, F. Organizational Behavior, 7th Edition. New York: McGraw Hill International, 1996.

Mahsun, Mohammad. Firma Sulistyowati, Heribertus Andre P. Akuntansi Sektor Publik. Yogyakarta: BPFE Yogyakarta, 2006.

Masyhuri dan M. Zainuddin. Metodologi Penelitian: Pendekatan Praktis dan Aplikatif. Bandung: Refika Aditama, 2009. 
Milliman, John, Andrew J. Czaplewski, dan Jeffery Ferguson. "Workplace Spirituality and Employee Work Attitudes: An Exploratory Empirical Assessment," Journal of Organizational Change Management 16, no. 4 (2003): 426-447.

Mowday, Richard T., Richard M. Steers, dan Lyman W. Porter. "The Measurement of Organizational Commitment", Journal of Vocational Behavior 14 (1979): 224-247.

Mulyono, Wastu Adi. "Hubungan Spiritualitas Di Tempat Kerja (STK) Dengan Komitmen Organisasi Perawat Di RSI Fatimah Cilacap." Tesis Magister, Universitas Indonesia, 2010.

Petchsawang, Pawinee dan Dennis Duchon, "Measuring Workplace Spirituality In An Asian Context", Human Resource Development International 12, no. 4 (2009): 459-468.

Priyasidharta, David. "Ribuan Jamaah Al-Khidmah Kirim Fatihah untuk TK". 24 Juli, 2016. https://m.tempo.co/amphtml/read/news/2013/06/09/078486824/ribuan-jamaah-alkhidmah-kirim-fatihah-untuk-tk.

Sheng, Chieh Wen dan Ming Chia Chen, "Workplace Spirituality Scale Design-The View of Oriental Culture", Business and Management Research 1, no.4 (2012): 46-62.

Starnes, Becky J. dan Stephen A. Truhon. A Primer on Organizational Commitment. Human Development and Leadership Division, 2006.

Sugiyono. Metode Penelitian Kuantitatif, Kualititatif, dan R\&D. Bandung: Alfabeta, 2015.

Yogatama, Leo Agung Manggala, dan Nilam Widyarini. "Kajian Spiritualitas Di Tempat Kerja Pada Konteks Organisasi Bisnis," Jurnal Psikologi 42, no. 1 (2015): 1-14. 